\title{
EFFECT OF SERVICE QUALITY ON SATISFACTION AND ITS IMPACT ON LOYALTY OF SANTRI PESANTREN STUDENT AL MA'SOEM
}

\author{
Dadang Dimyati \\ Program Studi Perbankan Syariah, Sekolah Tinggi Ilmu Perbankan Syariah \\ Al Ma'soem Bandung, Indonesia \\ dadangdimyati.mm.almasoem@gmail.com
}

\begin{abstract}
:
This study aimed to analyze the influence of service quality on satisfaction and the impacts on loyalty intention of students Al Ma'soem Boarding School. The research data was obtained from primary data by distributing questionnaires to 100 students of junior high school and senior high school in Al Ma'soem Boarding School. The findings of this study indicate that there is influence between the Service quality and satisfaction on the loyalty students in Al Ma'soem Boarding School. F test results showed that the Service quality and the satisfaction simultaneously affect to loyalty students in Al Ma'soem Boarding School. The R-square value obtained amounted to 0.417 , or $41,7 \%$, meaning that simultaneous Service quality and satisfaction contribute to the effect of $41,7 \%$ on loyalty students in Al Ma'soem Boarding School, as for the influence of others factors are $58,3 \%$.
\end{abstract}

Keywords : Service Quality, Satisfaction, and Loyalty.

\section{A. INTRODUCTION}

Education is a supporting factor that plays an important role in all sectors (van Hilten, 2015). Education is believed to be a strategic tool to improve human lives (Dunlosky, Rawson, Marsh, Nathan, and Willingham, 2013). Through education, people become intelligent (Asoni, 2011; Felder \& Brent, 2005), have the ability or skill (Bakan, 2000), a good attitude of life (Butt \& Shams, 2013), so can get along well in the community. Education becomes an investment (Mollet, 2007) that provides social and personal benefits (Baum \& Payea, 2005; Mitra, 2010) that make the nation dignified and individually into a degree of humanity (Lee, 2013).

The institution of education in this case Pesantren is, in essence, a conscious effort to increase the level of spiritual knowledge and practice for santri and institutions where the effort is rolling toward the goals on the set goals (Septalina Pradini, Hadi S Alikodra, Hasim, Tri Pranadji, 2016). In this position and role pesantren institution becomes a bastion of truth (Jannah, 2014) and honesty (Rasyid, 2014) that radiate its potential achievement to the surrounding community environment even for human beings (Mustari, 2013). Pesantren as education service providers need to learn and have an initiative to increase customer (in this case, santri) satisfaction (Agung, 2014), because education is a circular process that affect each other and sustainable (Mulford, 2003). Therefore, it is necessary to educate marketing services strategy to win competition among pesantren as well as to improve acceleration of quality and professionalism management of pesantren institution (Cf., Misdah, 2016). 
Pesantren Siswa Al Ma'soem (PSAM) was established in 2000 under the auspices of Al Ma'soem Foundation Bandung, providing special service of religious education to students of Al Ma'soem Junior High and High School who became a santri. Located on the street Cileunyi - Rancaekeuk number 22 Cipacing - Jatinangor - Sumedang. One of the characteristics of this pesantren is to accept only students who are junior high and high school students in Al Ma'soem school. To ensure the success of service quality in real customer service program (santri), it must get full support from all employees (Manager and Guardian santri) both support in the field of ability, expertise and motivation in implementing the program. Quality of service which is strategy to satisfy requirement of customer / santri also must be offset by superior quality of service offered to consumer / santri, so that consumer choose to use services offered. In addition, one of the strategies also applied by the founder of Al Ma'soem Foundation Bandung as well as founder of Pesantren Siswa Al Ma'soem (PSAM) alm. H. Nanang Iskandar Ma'soem in winning the competition is to make all Al Ma'soem junior and senior high school students become students of Pesantren Siswa Al Ma'soem. Therefore Pesantren Siswa Al Ma'soem (PSAM) requires alignment between work processes with stakeholders' interests (students, managers and users) in order to compete with other pesantren.

In total every year the number of students of Pesantren Al-Ma'soem enrollment changes, ie from academic year 2011/2012 as many as 244 students or $48.2 \%$, in the academic year 2012/2013 decreased to 231 students or $42.4 \%$, in the academic year $2013 / 2014$ rose to 300 santri or $55.3 \%$. in academic year 2014/2015 again increased to 336 santri or 59\% and decreased again in academic year 2015/2016 to 335 students or $59 \%$. Based on these data, it can be concluded that the average number of students who enter the pesantren every year about 256.6 rounded to 257 people or about $52.8 \%$.

Table 1

Number of Applicants From Junior High School Alumni

Pesantren Siswa Al Ma'soem

\begin{tabular}{cccc}
\hline Year & $\begin{array}{c}\text { Graduation Grade 9 } \\
\text { Junior High School } \\
\text { Number }\end{array}$ & $\begin{array}{c}\text { Number of Applicants } \\
\text { Alumni Junior High } \\
\text { School }\end{array}$ & $\begin{array}{c}\text { School } \\
\text { Percentage } \\
\text { Increase (\%) }\end{array}$ \\
\hline $\mathbf{2 0 1 0}$ & - & - & - \\
$\mathbf{2 0 1 1}$ & 157 & 20 & 12,74 \\
$\mathbf{2 0 1 2}$ & 145 & 34 & 23,45 \\
$\mathbf{2 0 1 3}$ & 187 & 46 & 24,60 \\
$\mathbf{2 0 1 4}$ & 103 & 45 & 43,69 \\
$\mathbf{2 0 1 5}$ & 107 & 55 & 51,40 \\
\hline
\end{tabular}

Source: Student Candidate Acceptance and Al Ma'soem Preaching

Based on table 1 above, it can be seen that the percentage of alumni of SMP per year keep increasing. Graduation Grade 9 declines in number from 2011 to 2014 except in 2013. The number of alumni who register from 2011 to 2015 continues to increase, only in 2014 has decreased even though only the difference of one applicant from 2013. The increase in percentage of the number of alumni applicants Junior high school to senior high school from 2011 to 2014 below 50\%, and in 2015 only reached $51.40 \%$ or an average increase of $31.18 \%$ per year.

To attract the intention of registering (repurchase intention) from the alumni of the junior high school students, the management of Pesantren Al-Ma'soem students also facilitates a reduction in the cost of 
education (discount) is greater when compared to applicants outside Al-Ma'soem Pesantren alumni, this can be seen in table 2 below.

Table 2

Rewards in the form of Education Tuition Fee Student Candidate of Pesantren Al Ma'soem Students (especially PSAM alumni)

\begin{tabular}{cc}
\hline Cost & Relief (\%) \\
\hline $\begin{array}{c}\text { Pesantren development } \\
\text { fund (DPP) }\end{array}$ & 50 \\
$\begin{array}{c}\text { Registration } \\
\text { Annual facility funding } \\
\text { (DAFT) }\end{array}$ & $\begin{array}{c}\text { Following the SMP } \\
\text { list time }\end{array}$ \\
\hline $\begin{array}{c}\text { Source: Student Candidate and Al-Ma'soem Section of Acceptance } \\
\text { S }\end{array}$
\end{tabular}

Based on table 2 above, it shows that for Al-Ma'soem Al-Pesantren students if registering back to Pesantren Al-Ma'soem students will get additional discount of 50\% DPP fee and free registration fee. While the cost of DAFT is given waivers follow the entry time of junior high school, so the overall cost of Al-Ma'soem students' alumni Pesantren is much cheaper than outside registrants.

Based on the results of the pre-survey questionnaire on Thursday, April 28, 2016 at Pesantren AlMa'soem students with the number of respondents 30 students and 14 questions about the satisfaction of students from the aspect of service quality in Pesantren Al-Ma'soem students in the answer agree I satisfied 205 (48.8\%) and disagree / not satisfied 215 (51.2\%). The dissatisfaction with the quality of service of Pesantren Al-Ma'soem students is suspected to be one indicator that causes many students not to enroll in Pesantren Al-Ma'soem students as it is a problem to be solved. For that Pesantren AlMa'soem students should focus more on the analysis of things that are desired candidate santri as a target market.

In relation to the above description, to win the competition among pesantren institutions and the effort to maintain the existing students, the researcher is interested to conduct more in-depth research focusing on the issue of "The Impact of Service Quality on Satisfaction and Its Impact on Student Loyalty of Pesantren Al Ma'soem ".

\section{Problem Identification}

Based on the above background, the problem identification in this research are :

a. Does the quality of service have an effect on the satisfaction of students of Pesantren Al Ma'soem students?

b. Does the santri's satisfaction affect the loyalty of Pesantren Al Ma'soem students?

\section{Research Objectives}

According to the identification of the proposed problem, the purpose of this research is :

a. To know whether the quality of service has an effect on the satisfaction of students of Pesantren Al 
Ma'soem students.

b. To find out whether the santri's satisfaction affect the loyalty of Pesantren Al Ma'soem students.

\section{Framework for Thinking}

Marketing activities can basically create and maintain exchange relationships (Kotler and Armstrong, 1996 \& Kotler and Keller, 2009). Consumer buying interest is a management goal to achieve success in marketing the product and it will be achieved if the company managed to give satisfaction to customers or able to produce good quality. The definition of service quality centered on efforts to meet the needs and desires of consumers and the accuracy of delivery to balance consumer expectations (Kotler and Armstrong, 1996 \& Kotler and Keller, 2009). If the service received in accordance with the expected, then the quality of service perceived good and satisfactory; if the service is accepted beyond consumer expectations then the quality of service is perceived as an ideal quality (Athoillah, 2010). In contrast, if the service received is lower than the consumer expected, then the quality is perceived poor. Thus the quality of service depends on the ability of the service owner to meet the consumer expectations consistently but dynamically by following the needs of consumers (Cf., Angelova \& Zekiri, 2011).

Consumer satisfaction is an essential element in any business activity. Because every satisfaction can lead to whether the customer we serve is satisfied with what we have given to the maximum and all that will be able to create customer loyalty to what has been obtained (Khan \& Fasih, 2014; Ahmed \& Rahman, 2015). The service provider will also benefit more if the customer is satisfied, he will also be able to make the consumer as a free marketer (Cf., Stucke, 2013). So, the main purpose of marketing is to achieve the highest level of customer satisfaction. In fact, lately much attention has been paid to "total" satisfaction whose implication is that reaching partial satisfaction alone is not enough to keep customers loyal and back again. When customers are satisfied with the service they are in during the transaction process and are also satisfied with the goods or services they receive, it is likely that they will return and make other purchases and will also recommend to friends and family about the company and its products and services.

A company must be able to give priority to good quality because that quality can affect customer satisfaction. To be able to win the competition with other companies, the company must be able to provide the maximum quality. Quality can provide the impetus to customers to forge a strong bond with the company (Cf., Petr Suchánek, Jiři Richter, \& Maria Králová, 2014). The ability to compete is the main reason for service providers to develop quality services according to quality standards and oriented to customer satisfaction. The services of such service providers need to be integrated by developing effective and efficient services in order to achieve low cost. According to Tjiptono (1997), if the quality of service produced superior from a large market share, then profitability will be guaranteed. So the quality of service and profitability are closely related. Tjiptono (1997) describes the attitude or way employees serve customers satisfactorily plays a major role in creating service excellence (service exellence). This advantage is established through the integration of four closely related pillars: speed, accuracy, friendliness, and service convenience. Every employee should have the skills to understand the product or service in depth and be able to communicate effectively with customers.

\section{B. METHOD}

\section{Research Paradigm}


According to Sugiyono (2004: 43) research paradigm is a mindset that shows the influence between variables to be examined yag at the same time reflects the type and number of formulas that need to be answered through research with theories used to formulate hypotheses, types and number of hypotheses, and technical statistical analysis will be used.

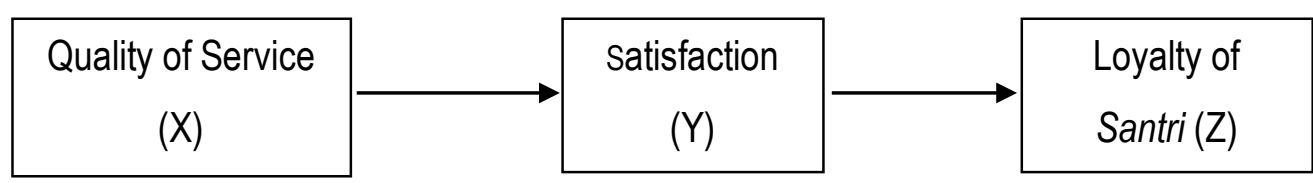

Figure 1

Research Thinking Framework

Information :

a. Independent variables: Variables that affect the dependent variable. Independent variables here are Quality of service (Tangibles, Responsiveness, Empathy, Assurance and Reliability) and Satisfaction of santri.

b. Dependent variable: Variable influenced by independent variable. The dependent variable here is loyalty.

It can be seen that consumer loyalty is influenced by the quality of service and customer satisfaction (Kotler \& Armstrong,1996; Kotler \& Shpëtim, 2012). Variables of service quality will result in customer satisfaction and loyalty (Kotler \& Keller, 2009 \& Jamaluddin \& Ruswanti, 2017), which will enable consumer buying interest (Mahfud \& Soltes, 2016). Perceptions of service quality determine customer satisfaction determine buying interest. Then the interaction between the quality of service and loyality of customers through customer satisfaction will determine consumer buying interest (Cf., Ganiyu, Uche, and Elizabeth, 2012 \& Çerri, 2012)

\section{Research Hypothesis}

Hypothesis is a proposition or a provisional suspicion that has not been tested whether it is true. Hipotesis is a provisional explanation (provisional explantion) about a phenomenon or an alternative solution to a problem. The hypothesis in this study are:

a. Hypothesis 1 : Quality of service has an influence on the satisfaction of students of Pesantren Siswa Al Ma'soem.

b. Hypothesis 2 : Satisfaction of students affects the loyalty of students of Pesantren Siswa Al Ma'soem.

\section{Research Design}

This research method using survey is research conducted on one population, the data studied is data from samples taken from the population, so it found relative events, distributive and relationship between sociological and psychological variables (Sugiyono, 2008: 7), the survey used is descriptive and verified survey with the concept of evaluation research.

\section{Population}


Population is a generalization region consisting of the object or subject that has certain qualities and characteristics set by the researcher to be studied and then drawn conclusions. (Sugiyono, 2013: 80). Another notion that the population is a collection of individuals who have certain characteristics set by the researchers (Reddy \& Acharyulu, 2009).

The population of analysis in the selected study were all students of SMP and SMA Pesantren Siswa AI Ma'soem in the academic year 2015/2016 which amounted to 875 people. While the location of research conducted in Pesantren Al Ma'soem Students are located at Jalan Cileunyi - Rancaekeuk number 22 Cipacing - Jatinangor - Sumedang.

\section{Sample}

The sample is defined as a subset or a subset of the population consisting of selected members of the population (Zulganef, 2008: 134). The sample is part of the number and characteristics possessed by that population. If the population is too large and the researcher is not possible to study everything in the population, for example due to limited funds, manpower and time, the researcher can use samples taken from the population to be really representative.

\section{Sampling Technique}

The sampling technique in this research is by using Non Probability Sampling, that is sampling technique which do not give equal opportunity or opportunity for every element or member of population to be chosen to be sample (Sugiyono, 2010: 122). Then the type of nonprobability sampling used in this study is purposive sampling because to obtain information from specific targets intentional by researchers (Zulganef, 2013: 146), in this case the sample used is students of junior high school and high school Pesantren Siswa Al ma'soem year 2016 amounted to 874 people (junior: son 295 - daughter and high school: son 210 - daughter 192). The minimum sample size will be used using the formulas from Taro Yamance or Solvin as dicutif (Riduwan and Kuncoro, 2013: 65) namely :

$n=\frac{\mathrm{N}}{N \cdot d^{2}+1} \quad=\frac{874}{874(0,1)^{2}+1}=89.73$

Information :

$N=$ The size of the sample drawn in the study

$N=$ The size of the study population

$d=$ Precision set

$1=$ Constant number

Precision value is set at $10 \%$ with a level of confidence (level of significant) of $90 \%$. Based on the number of population in the study ie students of junior high and high school level of 874 people, obtained a minimum sample size of 89.73 people and rounded 100 people. To know the size of the samples taken for each level is used proportional sampling technique using the following equation (Moh Nazir, 1988: 361):

$\mathrm{ni}=\mathrm{Ni} / \mathrm{N}$ xn

$n i=\frac{N i}{N} x n$

Information :

$n i=$ The sample size in the i-th strata

$\mathrm{Ni}=$ The size of the population in the stratum $\mathrm{i}$ 
$N=$ Total population size

$X n=$ Size of sample size

Based on the calculation of the sample using the formula above then the number of samples for each level can be seen in the following table:

Table 3

Number of Samples

\begin{tabular}{ccccc}
\hline & Level & Population & Sample & Amount \\
\hline \multirow{2}{*}{ SMP } & Male & 295 & $33.7 \%$ & 34 \\
& Female & 177 & $20.3 \%$ & 20 \\
SMA & Male & 210 & $24 \%$ & 24 \\
& Female & 192 & $22 \%$ & 22 \\
& Total & 874 & $100 \%$ & 100 \\
\hline
\end{tabular}

Source: Student Candidate Acceptance and Al Ma'soem Preaching

The number of samples in the above table is rounded up, to get the accuracy of the data, so the samples for each level become: junior men's 34, junior high school 20 and high school boy 24 , female high school 22 samples.

\section{Types and Sources of Research Data}

The type of data used in this study is quantitative data, where the data obtained in the form of the numbers of respondents answer where the answer is converted into numbers through Likert scale.

\section{RESULT AND DISCUSSION}

\section{Profile of Respondents}

Respondents in this study are students of SMP and SMA Pesantren Siswa Al Ma'soem who are still active as many as 100 respondents. To obtain information on the respondents in this study, the following will be described grouping of respondents based on: gender, domicile, education, and parent jobs.

\section{a. Gender}

Gender is a physical difference that characterizes whether the respondent is male or female. For more details can be seen in the following table:

Table 4

Composition of Respondents by Sex

\begin{tabular}{cccc}
\hline No & Gender & Total & Persentage (\%) \\
\hline 1 & Male & 58 & 58 \\
2 & Female & 42 & 42 \\
& Total & 100 & 100 \\
\hline
\end{tabular}

Source: Primary Data that is processed, 2016

Based on table 4 above, it is known that some respondents who become object in this research is men number 58 people (58\%) and female respondents known amounted to 42 people (42\%). 


\section{b. Respondent Domicile}

Based on respondent's domicile obtained table as follows:

Table 5

Composition of Respondents by Domicile

\begin{tabular}{|c|c|c|c|}
\hline No & Residential Area & Amount & $\begin{array}{c}\text { Percentage } \\
(\%)\end{array}$ \\
\hline 1 & Bandung Regency & 22 & 22 \\
\hline 2 & Bandung City & 24 & 24 \\
\hline 3 & Sumedang Regency & 5 & 5 \\
\hline 4 & Others & 49 & 49 \\
\hline \multicolumn{2}{|r|}{ Total } & 100 & 100 \\
\hline
\end{tabular}

Source: Primary Data that is processed, 2016

Based on table 5 above, it can be seen that most of the respondents who became the object in this study came from other districts of Bandung, Bandung and Sumedang district, while the details are as follows: the origin of the residence of Bandung regency is 22 people (22\%), Bandung area of 24 people $(24 \%)$, Sumedang district 5 people (5\%), and other regions 50 people $(50 \%)$.

\section{c. Education}

Viewed from the level of education of respondents who became the object in this study can be seen in table 6.

Table 6

Composition of Respondents by Education

\begin{tabular}{cccc}
\hline No & Education & Amount & Percentage (\%) \\
\hline 1 & SMP & 54 & 54 \\
2 & SMA & 46 & 46 \\
& Total & 100 & 100 \\
\hline
\end{tabular}

Source: Primary Data Processed, 2016

Based on table 6 above can be seen that most of the education level of respondents is the level of junior high. While the details are as follows: junior high school education amounted to 54 people (54\%) and high school education 46 people (46\%).

\section{d. Parents' job}

The work of respondent's parents who became the object in this research can be seen in table 7 below.

Table 7

Composition of Respondents Based on Parents' Work

\begin{tabular}{clcc}
\hline No & Parents' Job & Amount & Percentage (\%) \\
\hline $\mathbf{1}$ & Servant & 28 & 28 \\
$\mathbf{2}$ & Private Employees & 11 & 11 \\
$\mathbf{3}$ & Entrepreneur & 58 & 58 \\
$\mathbf{4}$ & Others & 3 & 3 \\
& $\quad$ Total & 100 & 100 \\
\hline
\end{tabular}


Based on table 7 above, it can be seen that the distribution of respondent's parents job in this research are: Public servant number 28 people (28\%), Private employee number 11 people (11\%), Entrepreneur / Entrepreneurs some 58 people (58\%) and another profession of 3 people $(7 \%)$.

\section{Test Validity}

Validity test is done by mengkolerasikan each statement with the number of scores of each variable.Validity is defined as sejuah where the accuracy and accuracy of a measuring instrument in performing its function. To test the validity of the measuring instrument, first searched the correlation price between the parts of the measuring instrument as a whole by correlating each item of the measuring instrument with the total score which is the sum of each score of the item, with the formula of Pearson Product Moment with the rule of decision as follows:

If $t$ _count $>t \_t a b e l$ means valid otherwise

t_count $<$ _t_table means valid otherwise

In this study, the authors test the level of validity of the questionnaire distributed to 100 respondents and the results of validity test processed by using the SPSS program produces data of each variable as follows:

\section{a. Validity Test of Variable X (Service Quality)}

Using 100 respondents, the $r$ table value can be obtained through $\mathrm{df}$ (degree of freedom) $=\mathrm{n}-2$. So $\mathrm{df}=$ $100-2=98$, then the $r$ table is 0.1654 . From result of data processing can be concluded that item question for service quality is valid.

\section{b. Test Validity Variable Y (Satisfaction)}

Using 100 respondents, the $r$ table value can be obtained through $\mathrm{df}$ (degree of freedom) $=\mathrm{n}-2$. So $\mathrm{df}=$ $100-2=98$, then the $r$ table is 0.1654 . From the results of data processing can be concluded that the question item for satisfaction is valid.

\section{c. Test of Variable Z Validity (Loyalty)}

Using 100 respondents, the $r$ table value can be obtained through $\mathrm{df}$ (degree of freedom) $=\mathrm{n}-2$. So $\mathrm{df}=$ $100-2=98$, then the $r$ table is 0.1654 . From result of data processing can be concluded that question item for loyalty is valid.

\section{Test Reliability}

A reliable instrument is an instrument that, when used multiple times to measure the same instrument, will produce the same data. Test reliability is used to determine the reliability or absence of an instrument so that can be trusted in research. The results of the reliability test processing for variables $X, Y$ and $Z$ by using SPSS as follows: 
Reliability Test Results

\begin{tabular}{|l|c|c|}
\hline \multicolumn{1}{|c|}{ Varibel } & $\begin{array}{c}\text { Cronbach' } \\
\text { s Alpha }\end{array}$ & $\begin{array}{c}\text { N of } \\
\text { Items }\end{array}$ \\
\hline Service Quality $(\mathrm{X})$ & .823 & 12 \\
\hline Satisfaction $(\mathrm{Y})$ & .730 & 4 \\
\hline Loyalty (Z) & .784 & 6 \\
\hline \multicolumn{2}{|c|}{ Source Questionnaire (data reprocessed) }
\end{tabular}

The reliability of a variable construct is said to be good if it has a cronbach's alpha value greater than 0.60 (Hayati and Son, 2007). From the table above can be seen that cronbach's alpha for variables $X, Y$ and $Z$ is greater than 0.60 . It can be concluded that the question items contained in the questionnaire for variables $X, Y$ and $Z$ are reliable.

\section{Simultaneous Hypothesis Test (F-Test)}

The simultaneous hypothesis formula that will be tested is as follows:

Ho: Service quality $(X)$ and satisfaction $(Y)$ together have no significant effect on Loyalty $(Z)$.

Ha: Service quality $(X)$ and satisfaction $(Y)$ together have a significant effect on Loyalty $(Z)$.

The significance level $(\alpha)$ is $5 \%$. Criterion of decision making:

Ho accepted, if F-count $<$ F-table at $\alpha=5 \%$

$\mathrm{Ha}$ is accepted, if F-count> F-table at $\alpha=5 \%$

By using the SPSS program obtained the following output:

Tabel 9

Tabel Anovab

\begin{tabular}{|l|c|c|c|c|c|}
\hline Model & $\begin{array}{c}\text { Sum of } \\
\text { Squares }\end{array}$ & Df & $\begin{array}{c}\text { Mean } \\
\text { Squar } \\
\mathrm{e}\end{array}$ & $\mathrm{F}$ & Sig. \\
\hline 1Regressio & 645.552 & 2 & 322.77 & 34.726 & .000 \\
$\mathrm{n}$ & & & 6 & & $\mathrm{a}$ \\
Residual & 901.608 & 97 & 9.295 & & \\
Total & 1547.160 & 99 & & & \\
\hline
\end{tabular}

a. Predictors: (Constant), X, Y

b. Dependent Variable: $Z$

Source: Questionnaire (data reprocessed)

Based on the above output known F-count value of 34.726 with $p$-value (sig) 0.000 . With $\approx 0.05$ and degrees of freedom df1 $=k-1=3-1=2$ and $d f 2=n-k=100-3=97$, we can see F-table 3.03. Due to F-count> F-table $(34,726>3.03)$, Ho is rejected and Ha accepted, meaning Service Quality $(\mathrm{X})$ and Satisfaction $(\mathrm{Y})$ together influence Loyalty $(\mathrm{Z})$.

\section{Partial Hypothesis Testing (t-Test)}

To test the hypothesis partially required table correlation coefficient, table correlation coefficient in question is as follows: 
Table 10

Table of Correlation Coefficients (t-test)

Correlations

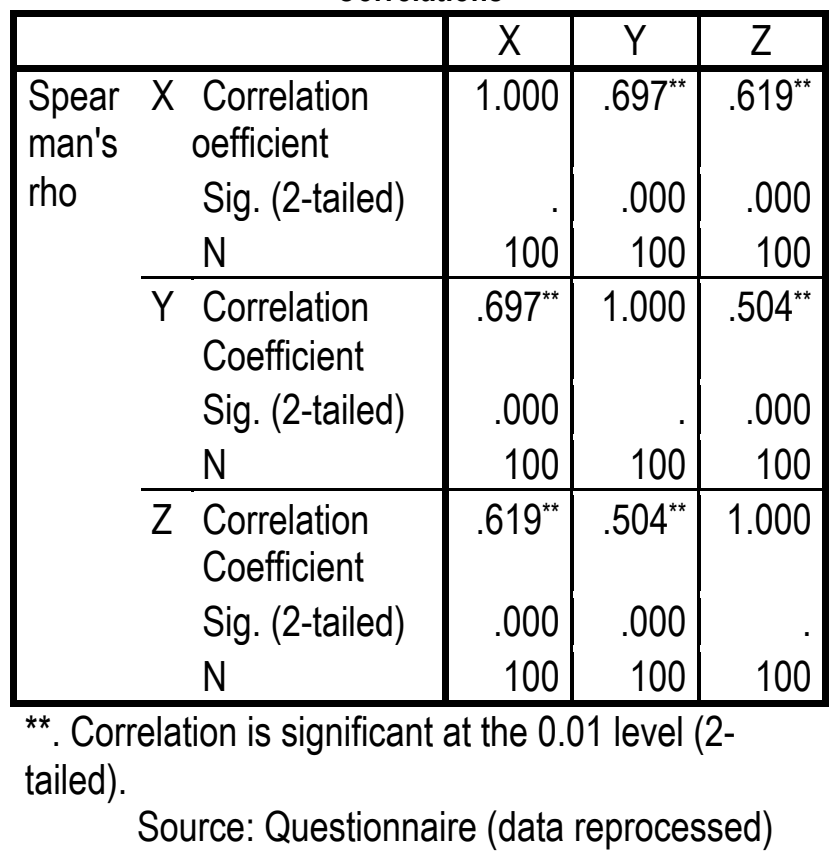

\section{a. Hypothesis Testing Variable X (Service Quality)}

Based on table 10 above, Spearman correlation coefficient rate between service quality variable to Satisfaction is 0.697 with a significance level of 0.000 at the 0.01 level. This means that statistically between the two variables are positively correlated with a perfect level of significance. A positive sign $(+)$ means the change in the numbers in both positive-positive variables. If Service Quality of Pesantren AlMa 'soem is improved then Satisfaction of santri Al Ma'soem students' pesantren will increase.

Ho: Service quality $(X)$ has no significant effect on Satisfaction $(Y)$.

Ha: Service quality $(X)$ has a significant effect on Satisfaction $(Y)$.

Since the Sig value of the above table is $0.000(<0.01)$ then $\mathrm{Ho}$ is rejected and Ha is accepted. Then from table 10 above also seen Spearman correlation coefficient correlation between Service quality variable to loyalty is equal to 0,619 with level of significance 0.000 at level 0,01 . This means that statistically between the two variables are positively correlated with the level of significance is perfect. A positive $(+)$ sign means a change in the numbers in both positive directional variables. If the quality of service (Pesantren) of Pesantren Al-Ma 'soem is improved then the Loyalty of students of Pesantren Al Ma'soem students will be higher.

Ho: Service quality $(X)$ has no significant effect on Loyalty $(Z)$.

Ha: Service quality $(X)$ has a significant effect on Loyalty $(Z)$.

Since the Sig value of the above table is $0.000(<0.01)$ then $\mathrm{Ho}$ is rejected and $\mathrm{Ha}$ is accepted.

\section{b. Hypothesis Testing Variable Y (Satisfaction)}

Based on table 10 above, Spearman correlation coefficient number between Satisfaction to Loyalty variable is 0.504 with a significance level of 0.000 at the 0.01 level. This means that statistically between the two variables are positively correlated with the level of significance is perfect. A positive $(+)$ sign means 
a change in the numbers in both positive directional variables. If the Satisfaction of students of Pesantren Al Ma'soem is improved then the loyalty of students of Pesantren Siswa Al Ma'soemakan is higher.

Ho: Satisfaction ( $Y$ ) has no significant effect on Loyalty (Z).

Ha: Satisfaction $(Y)$ has a significant effect on Loyalty $(Z)$.

Since the Sig value of the above table is $0.000(<0.01)$ then $\mathrm{Ho}$ is rejected and $\mathrm{Ha}$ is accepted.

\section{Coefficient of Determination}

Calculation of determination coefficient is done to know the influence or contribution variable of Service quality (X) and Satisfaction (Y) to Loyalty (Z). The formula according to (Sugiyono, 2012: 257) as follows: $\mathrm{Kd}=\mathrm{R}^{\wedge}(2) \times 100 \%$

Information :

$\mathrm{Kd}$ : Coefficient of Determination

$\mathrm{R}^{\wedge}(2)$ : The squared correlation coefficient

Table 11

Coefficient of Determination Model Summary

\begin{tabular}{|c|c|c|c|c|}
\hline Model & $\mathrm{R}$ & $\begin{array}{c}\mathrm{R} \\
\text { Square }\end{array}$ & $\begin{array}{c}\text { Adjusted } \\
\text { R Square }\end{array}$ & $\begin{array}{c}\text { Std. Error } \\
\text { of the } \\
\text { Estimate }\end{array}$ \\
\hline 1 & $.646^{\mathrm{a}}$ & .417 & .405 & 3.04876 \\
\hline
\end{tabular}

a. Predictors: (Constant), $X, Y$

In the data table (model summary), it can be seen that the value of $R$ square obtained is 0.417 or $41.7 \%$, meaning that simultaneously Service quality and Satisfaction contributes $41.7 \%$ influence to Loyality students of Pesantren Siswa Al Ma'soem, while the rest $\left(1-R^{2}\right)$ as much as $58.3 \%$ is the amount of contribution provided by other factors not examined, eg promotion (promotion), product (product) and word of mouth (WOM).

\section{CONCLUSION}

Based on the results of research and analysis on the effect of service quality on satisfaction and loyalty, it can be drawn conclusions as follows:

a. There is a positive effect of service quality on satisfaction. This is consistent with the partial test results that service quality is positively correlated with the correlation coefficient of 0.697 .

b. There is a positive effect of service quality on loyalty. This is consistent with the partial test results that service quality is positively correlated with the correlation coefficient of 0.619 .

c. There is a positive influence satisfaction on the loyalty of Pesantren Al Ma'soem students. This is consistent with the partial test results that perceived quality is positively correlated with a correlation coefficient of 0.504 .

d. Simultaneously there is a positive influence between service quality and satisfaction to the loyalty of Pesantren Student Al Ma'soem It is according to $\mathrm{F}$ test result which shows that Fcount> Ftable $(34,726>3,03), \mathrm{Ho}$ is rejected and $\mathrm{Ha}$ is accepted, its meaning service quality $(X)$ and satisfaction (Y) jointly affect the loyalty (Z).

Based on the conclusion above, the author's suggestions for Pesantren Al Ma'soem are as follows: 
a. Quality of service in Al Ma'soem Pesantren is good about 74\%, but there are still some shortcomings but not significant.

b. Pesantren Al Ma'soem must stick to the concept of "al muhaafadzotu 'alaa qodiimi sholih wal akhdil zaddiidi bil islah" maintain the positive values that have been owned and take something new with islah first.

c. It is expected that Pesantren Al Ma'soem can make Standard Operating Procedure (SOP) service to students, hold periodical training at least every three month about child psychology, conduct comparative study to other pesantren which have character of handling of same santri (boarding system) the addition of new lessons of kepesantrenan such as; Arabic, Nahwu Shorof, tafsir, hadith and yellow book.

\section{References}

Agung, Dwi. (2014). Pengaruh Kualitas Layanan dan Kinerja Karyawan terhadap Kepuasan Nasabah Koperasi Pondok Pesantren Mamba'ul Mubbasyirin Shiddiqiyyah Bojonegoro. Tesis Magister Program Studi Pendidikan Ekonomi Universitas Sebelas Maret Surakarta.

Ahmed, Selim \& Rahman, Md. Habibur. (2015). The Effects of Marketing Mix on Consumer Satisfaction: A Literature Review from Islamic Perspectives.Turkish Journal of Islamic Economics, Vol. 2, No. 1, February, pp. 17-30.

Angelova, Biljana \& Zekiri, Jusuf. (2011). Measuring Customer Satisfaction with Service Quality Using American Customer Satisfaction Model (ACSI Model). International Journal of Academic Research in Business and Social Sciences, Vol. 1, No. 3, October, pp. 232-258.

Asoni, Andrea. (2011). Intelligence, Self-confidence and Entrepreneurship. IFN Working Paper No. 887. Research Institute of Industrial Economics P.O. Box 55665 SE-102 15 Stockholm, Sweden info@ifn.se; www.ifn.se (accessed 2 September 2017).

Athoillah, M. Anton. (2010). Dasar-dasar Manajemen. Bandung, Pustaka Setia.

Bakan, Ismail. (2000). The Importance of Formal Employee Education in The World of Growing Uncertainty. Turkey: Unpublished manuscript, Sutcu Imam University. www.opf.slu.cz/vvr/akce/turecko/pdf/bakan.pdf (accessed 1 September 2017).

Baum, Sandy \& Payea, Kathleen. (2005). The Benefits of Higher Education for Individuals and Society. Trends in Higher Education Series Revised Edition, www.collegeboard.com (accessed 2 September 2017).

Butt, Intzar Hussain \& Shams, Jahan Ara. (2013). Master in Education Student Attitudes towards Research: A Comparison between two Public Sector Universities in Punjab. South Asian Studies A Research Journal of South Asian Studies. Vol. 28, No. 1, January - June, pp. 97105.

Dunlosky, John; Rawson, Katherine A.; Marsh, Elizabeth J.; Nathan, Mitchell J.; \& Willingham, Daniel T. (2013). Improving Students' Learning with Effective Learning Techniques: Promising Directions from Cognitive and Educational Psychology. Psychological Science in the Public Interest, Vol. 14 (1), pp. 4-58, http://dx.doi.org/10.1177/1529100612453266

Felder, Richard M. \& Brent, Rebecca. (2005). Understanding Student Differences. Journal of Engineering 
Education, Vol. 94 (1), pp. 57-72.

Ganiyu, Rahim Ajao; Uche, Ignatius Ikechukwu; \& Elizabeth, Adeoti Olusola. (2012). Is Customer Satisfaction an Indicator of Customer Loyalty? Australian Journal of Business and Management Research, Vol. 2 No.07, October, pp. 14-20.

http://dx.doi.org/10.15238/tujise.2015.2.1.17-30

Jamaluddin \& Ruswanti, Endang. (2017). Impact of Service Quality and Customer Satisfaction on Customer Loyalty: A Case Study in a Private Hospital in Indonesia. IOSR Journal of Business and Management (IOSR-JBM). Volume 19, Issue 5. Ver. I, May, pp. 23-33, http://dx.doi.org/10.9790/487X-1905012333

Jannah, Hasanatul. (2014). Pesantren dan Pusat Konseling Bagi Generasi Muda. Konseling Religi: Jurnal Bimbingan Konseling Islam. Vol. 5, No. 1, Juni, pp. 95-114.

Khan, Mubbsher Munawar \& Fasih, Mariam. (2014). Impact of Service Quality on Customer Satisfaction and Customer Loyalty: Evidence from Banking Sector. Pakistan Journal of Commerce and Social Sciences. Vol. 8 (2), 331- 354.

Kotler \& Kevin Lane Keller. (2009). Marketing Management, Volume One, (Indonesian edition), Thirteenth Edition. Jakarta: Erlangga.

Kotler, Philip and Gary Armstrong. (1996). Principles Of Marketing, Seventh Edition, International Editrion. Prentice Hall, Inc., Englewood Cliffs, New Jersey.

Lee, Sharon E. (2013). Education as a Human Right in the 21st Century. Democracy \& Education, Vol. 21, No. 1, pp. 1-9.

Mahfud, Mr. Abdlhakim Giuma \& Soltes, Vincent. (2016). Effect Of E-Service Quality on Consumer Interest Buying (Case Study on The Website Korean Denim). IOSR Journal of Economics and Finance (IOSR-JEF). Volume 7, Issue 4. Ver. I (Jul. - Aug), pp. 61-67, http://dx.doi.org/10.9790/5933-0704016167

Misdah. (2016). Management Strategic Development of Boarding School (Between the Theory and Application). Pesantren Management and Development towards Globalization (Proceeding of 1st International Conference of Pesantren UIN Maulana Malik Ibrahim Malang)

Mitra, Dhana. (2010). The social and economic benefits of public education (Doctoral dissertation, Pennsylvania State University). Retrieved from http://www.elc-pa.org/wpcontent/ uploads/2013/11/Bestlnvestment_Full_Report_6.27.11.pdf.

Mollet, Julius Ary. (2007). Educational investment in conflict areas of Indonesia: The case of West Papua Province. International Education Journal, 2007, Vol 8, (2), pp. 155-166.

Mulford, Bill. (2003). School Leaders: Changing Roles and Impact on Teacher and School Effectiveness. A paper commissioned by the Education and Training Policy Division, OECD, for the Activity Attracting, Developing and Retaining Effective Teachers; https://www.oecd.org/edu/school/2635399.pdf (accessed 1 September 2017).

Mustari, Mohamad. (2013). The Roles of the Institution of Pesantren in the Development of Rural Society: A Study in Kabupaten Tasikmalaya, West Java, Indonesia. International Journal of Nusantara Islam, Vol. 1, No. 1, pp. 13-35. http://dx.doi.org/19.15575/ijni.v1i1.34 
Pradini, Septalina; Alikodra, Hadi S.; Hasim; \& Pranadji, Tri. (2016). Pesantren Transformation System in the Food Sustainability. International Journal of Development and Economic Sustainability. Vol.4, No.2, April, pp.1-18

Rasyid, Ramli. (2014). Tantangan Lembaga Pendidikan Islam Sebagai Benteng Pertahanan Moral Bangsa. Lentera Pendidikan, Vol. 17, No. 2, Desember, pp. 243-255.

Shpëtim, Çerri. (2012). Exploring the Relationships among Service Quality, Satisfaction, Trust and Store Loyalty among Retail Customers. Journal of Competitiveness, Vol. 4, Issue 4, pp. 16-35, December, http://dx.doi.org/10.7441/joc.2012.04.02

Stucke, Maurice E. (2013). Is competition always good? Journal of Antitrust Enforcement. Vol. 1, No. 1 (2013), February, pp. 162-197, http://dx.doi.org/10.1093/jaenfo/jns008

Sugiyono. (2004). Statistics For Research. Bandung: Alfabeta. Tjiptono, Fandy. (1997). Marketing Strategy. Second Edition, First Print. Yogyakarta: Andi Offset.

van Hilten, Lucy Goodchild. (2015). Higher education is key to economic development (but it's not as simple as you think): We need to look at geography, skills and local companies to accelerate development. https://www.elsevier.com/atlas/story/people/higher-education-is-key-toeconomic-development (accessed 1 September 2017). 